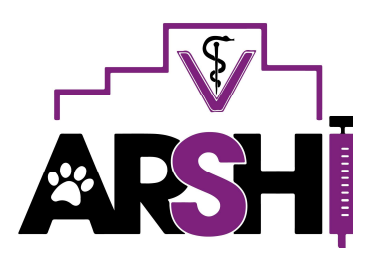

\title{
Suspect chronic kidney disease pada kucing domestik
}

\author{
Muhamad Arfan Lesmana*, Syakina Wahyu Endah Puspita \\ Klinik Hewan Pendidikan, Fakultas Kedokteran Hewan, Universitas Brawijaya, Kota Malang, Jawa Timur
}

\begin{abstract}
ABSTRAK: Kucing domestik didiagnosa suspect chronic kidney disease (CKD) di Klinik Hewan Pendidikan, Fakultas Kedokteran Hewan, Universitas Brawijaya, Malang. Chronic kidney disease atau gagal ginjal kronis merupakan suatu kondisi dimana ginjal mengalami penurunan kinerja secara progresif sehingga tubuh gagal untuk mempertahankan metabolisme serta keseimbangan cairan dan elektrolit, dimana penyakit ini dapat bersifat reversibel dan irreversibel. Studi kasus ini membahas cara pendiagnosaan dan penanganan terhadap kasus suspect CKD. Diagnosa dilakukan dengan cara melakukan pemeriksaan fisik dan penegakkan diagnosa dengan pemeriksaan urinalisis, hematologi, kimia darah dan pencitraan ultrasonografi. Pengobatan terhadap kasus suspect CKD dilakukan adalah dengan menggunakan amoxicillin, livron, metronidazole selama 5 hari.
\end{abstract}

Kata kunci:

kucing, chronic kidney disease

\section{- PENDAHULUAN}

Chronic kidney disease (CKD) atau gagal ginjal kronis adalah suatu sindrom klinis yang disebabkan penurunan fungsi ginjal yang bersifat menahun, berlangsung progresif yang akhirnya akan mencapai gagal ginjal terminal (O'Neill 2013). Chronic kidney disease merupakan suatu kondisi dimana ginjal mengalami penurunan kinerja secara progresif sehingga tubuh gagal untuk mempertahankan metabolisme serta keseimbangan cairan dan elektrolit, dimana penyakit ini bersifat persisten dan irreversibel (Suhardjono 2001).

Menurut Suwitra (2006), beberapa penyebab yang berpotensi menyebabkan terjadinya CKD yaitu usia, genetik, lingkungan, malformasi konginetal ginjal (cacat lahir), infeksi bakteri kronis ginjal dengan atau tanpa batu ginjal (pielonefritis), tekanan darah tinggi (hipertensi), penyakit yang berhubungan dengan sistem kekebalan tubuh (seperti glomerulonefritis, systemic lupus), penyakit ginjal akut dan obat-obatan tertentu seperti NSAID. Studi kasus ini membahas tentang cara pendiagnosaan dan penanganan terhadap kasus suspect chronic kidney disease (CKD).

\section{- KASUS}

Anamnesa dan Sinyalemen: Seekor kucing domestik dibawa ke Klinik Hewan Pendidikan, Fakultas Kedokteran Hewan, Universitas Brawijaya, Malang pada 5 Juli 2019 dengan keluhan selama seminggu nafsu makan menurun, terlihat kondisi kucing sangat kurus dan mengalami penurunan berat badan. Kucing ini minum sangat banyak dan urinasi banyak sedikit berdarah, makan basah mau sedangkan pakan kering tidak mau. Mulut kucing bau tidak enak.

Pemeriksaan Fisik: Berat badan 2,9 kg dengan suhu tubuh $37,8^{\circ} \mathrm{C}$, kondisi umum hewan sedikit lemas dengan membran mukosa berwarna pink pucat. Pemeriksaan status dehidrasi hewan dengan CRT $>2$ detik dan turgor kulit selama $>2$ detik.
Hewan dicoba disuapi dengan pakan basah menunjukkan reflek mau menelan makanan. Kucing mengeluarkan bau mulut yang tidak enak.

Pemeriksaan Penunjang: Pemeriksaan hematologi dan kimia darah dilakukan di Laboratorium Patologi Klinik, Fakultas Kedokteran, Universitas Brawijaya, Malang (Gambar 1A). Pemeriksaan urinalisis dan ultrasonografi (USG) dilakukan di Klinik Hewan Pendidikan, Fakultas Kedokteran Hewan, Universitas Brawijaya, Malang (Gambar 1B-D).
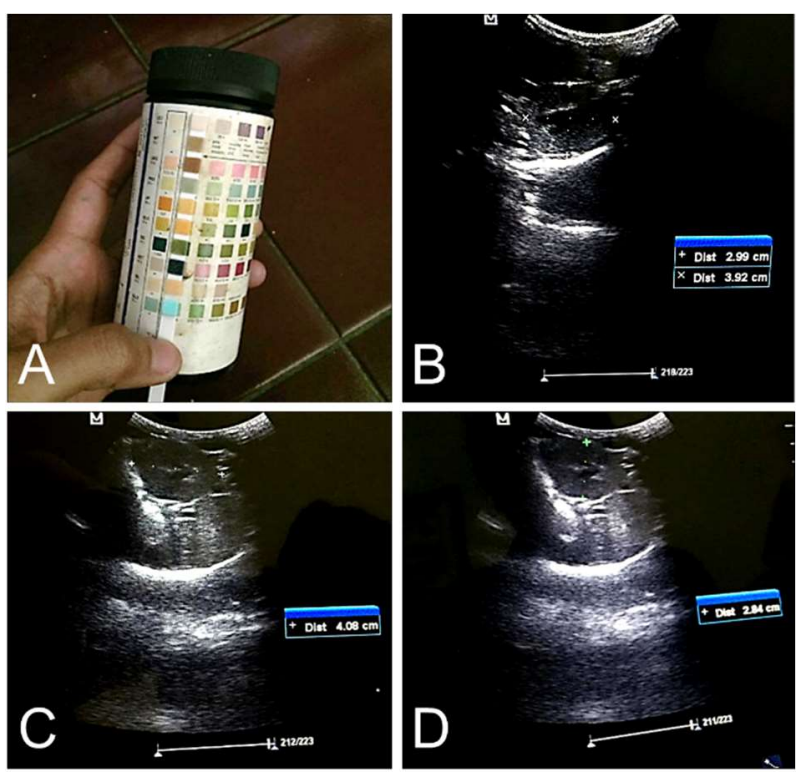

Gambar 1. Pemeriksaan penunjang pada kucing. (A) urinalis, (B) ultrasonografi (USG) ginjal kanan, (C dan D) ginjal kiri.

Diterima: 10-06-2020 | Direvisi: 09-07-2020 | Disetujui: 19-07-2020

(C) 2020 CC-BY-SA. Ini adalah artikel Open Access yang didistribusikan berdasarkan ketentuan dari Creative Commons Attribution ShareAlike 4.0 International License (https://creativecommons.org/licenses/by-sa/4.0/). 
Diagnosa: Hewan didiagnosa suspect CKD berdasarkan pemeriksaan fisik, hematologi, kimia darah, urinalisis, dan ultrasonografi (USG). Prognosa: Dubius infausta. Terapi dan Penanganan: Terapi yang diberikan selama dirawat di Klinik Hewan Pendidikan, Fakultas Kedokteran Hewan Universitas Brawijaya yaitu amoxicillin, livron, dan metronidazole selama 5 hari, serta pakan basah Whiskas ${ }^{\circledR}$.

\section{- HASIL}

Hasil pemeriksaan hematologi kucing di dapatkan hasil yaitu leukosit meningkat menjadi $21,9103 / \mu \mathrm{L}$, dari nilai normal 5,5 - 19,5 103/ $\mu \mathrm{L}$. Sedangkan terjadi penurunan pada Eritrosit menjadi 3,42 106/ $\mu \mathrm{L}$, dari angka normal 5,0 - 10,0 $106 / \mu \mathrm{L}$; hemoglobin menjadi 5,9 g/dL, dari angka normal 8,0 - 15,0; dan Hematokrit menjadi $18,3 \%$, dari angka normal 24,0 - 45,5\%. Hasil pemeriksaan kimia darah kucing di dapatkan hasil yaitu Ureum/BUN meningkat menjadi $354 / 165 \mathrm{mg} / \mathrm{dL}$, dari angka normal 15-34 mg/dL; Kreatinin meningkat menjadi $10,5 \mathrm{mg} / \mathrm{dL}$, dari nilai normal $0,9-2,1$ $\mathrm{mg} / \mathrm{dL} ;$ AST/SGOT meningkat menjadi $75 \mathrm{IU} / \mathrm{L}$, dari nilai normal 9,2 -39 IU/L; ALT/SGPT meningkat menjadi 118 IU/L, dari nilai normal 28-76 IU/L; Albumin menurun menjadi 2,1 g/dL, dari nilai normal 2,8 -5,5 g/dL (Wirawan 2011).

Hasil urinalisis kucing di dapatkan hasil yaitu berat jenis urin 1,007 menunjukkan terjadinya penurunan dari normalnya yaitu 1,008-1,015. Hasil pemeriksaan USG menunjukkan ukuran panjang dan lebar ginjal kiri kucing yaitu $31,1 \mathrm{~mm}$ dan $28,7 \mathrm{~mm}$. Sedangkan untuk panjang dan lebar ginjal kanan kucing yaitu 39,8 mm dan 31,2 mm. Menurut (Barr 2011), ukuran normal panjang ginjal kucing yaitu $30-45 \mathrm{~mm}$.

\section{- PEMBAHASAN}

Hasil pemeriksaan hematologi menunjukkan terjadinya anemia. Anemia merupakan pengurangan jumlah sel darah merah, kuantitas hemoglobin, dan volume padat sel darah merah atau hematokrit. Kondisi anemia pada kasus kucing suspect CKD yaitu anemia non regeneratif yang ditunjukkan adanya penurunan nilai RBC, hemoglobin, dan hematocrit sedangkan MCV dan MCHC normal. Anemia ini disebabkan oleh perubahan pada sintesis erythropoietin, yaitu hormon yang mengatur eritropoiesis pada ginjal. Eritropoietin berfungsi merangsang sumsum tulang untuk memproduksi sel darah merah, eritropoietin merupakan regulator utama pembentukan eritrosit. Kondisi tersebut menunjukkan bahwa terjadi penurunan fungsi ginjal yang berlangsung beberapa minggu yang menyebabkan depresi tulang belakang karena adanya penyakit ginjal yang bersifat kronis (Wirawan 2011).

Hasil pemeriksaan urinalisis terjadi penurunan berat jenis urin dapat menandakan terdapat kerusakan atau abnormalitas pada fungsi ginjal. Hasil urinalisis juga terdapat protein. Kegagalan fungsi atau gangguan yang terjadi secara kronis pada ginjal tentunya akan mempengaruhi sistem metabolik karena ginjal memiliki peran yang sangat penting dalam sirkulasi dan filtrasi zat-zat dalam tubuh. Proteinuria menandakan adanya gangguan pada filtrasi glomerulus sehingga meningkatkan permeabilitas dari glomerular yang menyebabkan protein dan glukosa tidak tersaring dan terekskresi dalam urin (Wirawan, 2011). Hasil pemeriksaan USG terlihat ginjal kucing mengecil. Hal tersebut disebabkan karena adanya atropi pada ginjal, sebagai salah satu ciri terjadinya CKD (Polzin 2011). Perdarahan dalam urin kucing menunjukkan adanya infeksi saluran perkemihan yang dapat diberikan antibiotika (Plumb 2011).

Terapi yang dilakukan yaitu pemberian antibiotik amoxicillin, multivitamin livron, dan metronidazole selama 5 hari dan pakan basah Whiskas ${ }^{\circledR}$ untuk menambah nafsu makan. Hewan dengan kasus CKD sebaiknya diberikan terapi tambahan infus Sodium Chloride 0,9\% untuk mengatasi dehidrasi dengan mengatur distribusi cairan, keseimbangan elektrolit dan tekanan osmotik cairan tubuh; Azodyl ${ }^{\circledR}$ untuk menurunkan kadar ureum dan kreatinin dalam darah; Sangobion ${ }^{\circledR}$ untuk membantu proses pembentukan hemoglobin dan sel darah merah sehingga dapat mengatasi anemia; dan pemberian pakan Renal ${ }^{\circledR}$ yang diformulasi khusus untuk hewan penderita penyakit ginjal kronis pada umumnya mengandung protein terbatas. Pakan dengan kandungan protein rendah mampu menurunkan kadar BUN dan tingkat kematian pada anjing penderita penyakit ginjal kronis (Polzin 2011).

\section{- SIMPULAN}

Kucing pada kasus ini didiagnosa suspect chronic kidney disease berdasarkan pemeriksaan fisik, hematologi, kimia darah, urinalisis, dan ultrasonografi (USG). Terapi pendukung berupa pemberian antibiotik dan multivitamin dapat mendukung perbaikan kondisi kucing.

\section{- INFORMASI PENULIS}

Penulis untuk Korespondensi

* MAL: arfan_lesmana@ub.ac.id

Departemen Klinik Hewan Pendidikan, Fakultas Kedokteran Hewan, Universitas Brawijaya, Malang, INDONESIA

\section{- PUSTAKA ACUAN}

Barr F, Gaschen L. 2011. BSAVA manual of Canine and Feline Ultrasonography. British Small Animal Veterinary Association.

O'neill DG, Elliott J, Church DB, McGreevy PD, Thomson PC, Brodbelt DC. 2013. Chronic kidney disease in dogs in UK veterinary practices: prevalence, risk factors, and survival. Journal of Veterinary Internal medicine 27(4): 814-821.

Plumb DC. 2011. Veterinary Drug Handbook. 7th Edition. Pharma Vet Inc: Stockholm, Wisconsin.

Polzin DJ. 2011. Chronic kidney disease in small animals. Veterinary Clinics: Small Animal Practice 41(1): 15-30.

Suhardjono 2001. Gagal Ginjal Kronik. Buku Ajar Ilmu Penyakit Dalam Jilid II. Edisi ketiga. Jakarta: FK UI.

Suwitra K. 2006. Penyakit Ginjal Kronik. Buku Ajar Ilmu Penyakit Dalam Jilid I. Pusat Penerbitan Departemen Ilmu Penyakit Dalam Jakarta: FK UI.

Wirawan R. 2011. Pemeriksaan Laboratorium Hematologi (Pertama). Jakarta: FK UI. 